\title{
Cliticization as Extraction: The Big DP Hypothesis Revisited
}

\author{
Anna Cardinaletti \\ Università Ca’ Foscari, Venezia
}

\begin{abstract}
:
In this paper, it is argued that cliticization is extraction out of a big DP. Big DPs contain both clitic pronouns and associate DP arguments (Torrego, 1995; Uriagereka, 1995, 2005, among others). The DP can be pronounced, which gives rise to a clitic doubling configuration, or can be null, in which case a simple clitic configuration is obtained. This hypothesis allows us to explain not only the limited movement possibilities of clitic pronouns (cf. Belletti 1999), but also their restricted inventory: Not all complements can be cliticized. If clitic pronouns are reduced maximal projections (Cardinaletti and Starke, 1999), the big DP hypothesis needs to be revisited. Clitic pronouns cannot be assumed to be the heads of big DPs, as was suggested in the abovementioned proposals. The proposal is that clitic pronouns are merged as specifiers of the highest projection of big DPs, namely $\mathrm{K}($ ase)P, which also captures the fact that they are the only elements which bear morphological case in languages like Italian.
\end{abstract}

Keywords: Clitic pronouns; extraction; clitic inventory; big DP hypothesis; case projection

\section{Clitic pronouns}

Clitic pronouns as in Italian (1) are unstressed, monosyllabic arguments subject to movement and with unrestricted reference. They build a minimal pair with stressed monosyllabic words, as in Italian (2), and contrast with bisyllabic strong pronouns as in Italian (3a) or Portuguese (3b). They cannot remain in their first merge position (4a), contrary to strong pronouns (4b). They are compatible with any type of referent, (5a), while strong pronouns can only refer to human beings $(5 \mathrm{~b}):^{1}$

(1) La conosco.

[I] her know

'I know her'

(2) [la] vs ['la]

'her' 'there'

(3) a. [li] vs. [loro]

'them' 'them'

b. [a] vs. [ela]

'her' 'her'

(4) a. *Conosco la.

[I] know her

b. Conosco lei.

'I know her'

\footnotetext{
${ }^{1}$ For the properties of clitic vs. strong pronouns, see Kayne (1975) and Cardinaletti \& Starke (1999).
} 
(5) a. La conosco/mangio.

[I] her/it know/eat

'I know her/eat it'

b. Conosco/*mangio lei.

'I know/*eat her'

Clitic pronouns raise a number of questions for syntactic theory. They concern:

1) the format of syntactic structures: do clitic pronouns realize a reduced structure with respect to the phrases they stand for?

2) the type of movement involved: do clitic pronouns involve an instance of head movement or XP movement?

3) the inventory of syntactic categories: do clitic pronouns realise the same category D as determiners or a different category?

Clitic pronouns are generally claimed to have a reduced structure with respect to strong pronouns and full DPs. Many scholars suggested that clitic pronouns are D heads (Torrego, 1988; Cardinaletti, 1994; Uriagereka, 1995, 2005; Corver \& Delfitto, 1999; Duarte \& Matos, 2000, among many others). The triggering of past participle agreement as in (6) has led scholars to consider clitic pronouns as maximal projections and to regard cliticization as a two-step process: XP-movement followed by X-movement (Sportiche, 1989/98; Belletti, 1999; Cardinaletti \& Starke, 1999; Rizzi, 2000):

(6) Questi libri, Gianni li ha letti.

these books, Gianni them has read.M.PL

The XP-step of clitic movement parallels A-movement found in passive sentences (7b) and sentences containing unaccusative verbs (8), which also triggers past-participle agreement (signalled in bold):

(7) a. Gianni ha letto questi libri.

Gianni has read these books

b. Questi libri sono stati letti. these books have been.M.PL read.M.PL

(8) Questi libri sono arrivati ieri. these books are arrived.M.PL yesterday

If morphological agreement is the reflex of a local relationship (spec-head agreement, Kayne 1989), (9a,b) is the structure of (7b) and (8), respectively, and (9c) the structure of (6):

(9) a.[тр Questi libri sono [partp questi libri-stati [partP questilibri letti b.[тр Questi libri sono_ [PartP questi libri arrivati c. [TP Gianni [T li ha] [PartP li letti

\author{
[vp letti questi libri]]]]]. \\ [vp arrivati questi libri]]]. \\ [vp Gianni letti li]]].
}

In (9c), the clitic pronoun is first merged as a maximal projection and raises as such to the specifier of the projection containing the past participle. The second step of clitic movement is head movement: the pronoun raises to the functional head $\mathrm{T}$ which contains the finite verb (here, auxiliary ha 'has'). 
In this paper, the structure realised by clitic pronouns and the nature of clitic movement are addressed again trying to answer two more questions: i) why is clitic movement restricted?, and ii) why is the availability of clitic pronouns in Romance languages restricted to some complements?

In the two next sections, the empirical data are presented. In section 4, we show that the two sets of data can be formulated as a single generalization, which in turn can be captured by a single hypothesis: clitic pronouns are merged as constituents of big DPs. In section 5, we analyse the internal structure of big DPs and suggest that a clitic pronoun is a reduced maximal projection merged as the specifier of the big DP. Section 6 is devoted to the analysis of the generalization arrived at in section 4. Section 7 concludes the paper.

\section{The extraction possibilities}

In the long-standing debate about the nature of clitic placement, whether due to movement (Kayne, 1975 ) or the insertion of the pronoun in its surface position (Jaeggli, 1982), the extraction possibilities of clitic pronouns have been studied in detail. Consider the contrast between (10) and (11), discussed by Belletti \& Rizzi (1981): in (10), the quantified nominal expression is the internal argument of the transitive verb trascorrere 'spend', and clitic extraction is possible (10b), while in (11), it is an adjunct of the unaccusative verb rimanere 'stay', and clitic extraction is impossible (11b): ${ }^{2}$

(10) a. Gianni trascorrerà [QP tre [DP settimane]] a Milano.

Gianni will.spend three weeks in Milan

b. Gianni ne trascorrerà [QP tre ne] a Milano.

Gianni of.them will.spend three in Milan

(11) a. Gianni è rimasto [QP tre [DP settimane]] a Milano.

Gianni has stayed three weeks in Milan

b. *Gianni ne è rimasto [QP tre ne] a Milano.

Gianni of.them has stayed three in Milan

These data show that VP-internal complements allow the extraction of a clitic pronoun, while adjuncts do not.

Also consider the extraction of the clitic complement of the lexical preposition accanto 'near' in (12b):

(12) a. Maria è / sta [pp accanto [pp a Gianni]].

Maria is / stays near to Gianni

b. Maria gli è / sta [pp accanto gli].

Maria to.him is / stays near

Rizzi (1988/2001:540) observed that the clitic complement of accanto can be extracted when the PP is an argument of the predicate mettersi 'put himself' (13b) or a VP-complement occurring with the verb mangiare 'eat' in (14b), but ungrammatical when the PP is an adjunct of essere felice 'be happy' (15b) (also see Siloni, 1997:64,n.27 and Belletti, 1999:557-558):

\footnotetext{
${ }^{2}$ The quantified nominal expression in (10) is analysed as the QP projection of the quantifier tre 'three' (cf. Cardinaletti \& Giusti 2006, 2017). In (10b) and all examples below, barred character signals the first merge position of moved elements.
} 
(13) a. Gianni si è messo [pp accanto [pp a Maria]].

Gianni himself put near to Maria

'Gianni put himself near Maria'

b. Gianni le si è messo [pp accanto le].

Gianni to.her himself put near

'Gianni put himself near her'

(14) a. Gianni ha mangiato [pp accanto [pP a Maria]].

Gianni has eaten near to Maria

'Gianni ate near Maria'

b. ?Gianni le ha mangiato [pp accanto łe].

Gianni to.her has eaten near

'Gianni ate near her'

(15) a. Gianni è felice [pp accanto [pp a Maria]].

Gianni is happy near to Maria

'Gianni is happy near Maria'

b. *Gianni le è felice [pp accanto le].

Gianni to.her is happy near

'Gianni is happy near her'

Note that the contrast between (13)-(14) on the one hand and (15) on the other is replicated in the case of wh-extraction, both in the case of relative clauses (16) (examples from Rizzi 1988/2001:540), and whquestions (17). In order to obtain a grammatical sentence in the case of adjunct PPs, pied piping is obligatory, (16c) vs. (16d), (17c) vs. (17d):

(16) a.La ragazza alla quale Gianni si è messo [Pp accanto allaquale]

the girl to whom Gianni himself put near

'the girl near whom Gianni put himself'

b.?La ragazza alla quale Gianni ha mangiato [PP accanto alla quale] the girl to whom Gianni has eaten near

'the girl near whom Gianni ate'

c. *La ragazza alla quale Gianni è felice [pp accanto alla quale]

the girl to whom Gianni is happy near

d.La ragazza [PP accanto [PP alla quale]] Gianni è felice aceante allaquale

the girl near to whom Gianni is happy

'The girl near whom Gianni is happy'

(17) a.A chi si è messo [PP accanto chi]?

to whom [he] himself has put near

'Near whom did he put himself?'

b.?A chi ha mangiato [PP accanto chi]?

to whom [he] has eaten near

'Near whom did he eat?'

c.*A chi è felice [pp accanto chi]?

to whom [he] is happy near 


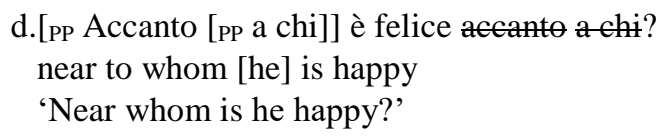

A similar contrast is found with manner complements. Rizzi (1988/2001:540) observes that the complement of the preposition senza 'without' (18a) can be extracted through the clitic ne (18b). Example (18c) shows that it can expectedly also be wh-moved. Note that the PP in (18) is a manner argument of the verb rimanere 'remain'. On the basis of the contrast between arguments and adjuncts seen above, we expect that extraction is not possible when the PP is a manner adjunct. This is indeed the case, as examples $(19 \mathrm{~b}, \mathrm{c})$ containing partire 'leave' show; pied-piping is again obligatory (19d):

(18) a. Sono rimasto [PP senza [DP sigarette]].

[I] have remained without cigarettes

b. Ne sono rimasto [pp senza ne].

[I] of.them have remained without

c. Di cosa sei rimasto [pP senza cosa]?

of what [you] have remained without

(19) a.Sono partito [pP senza [DP sigarette]].

[I] have left without cigarettes

b. ${ }^{*} \mathrm{Ne}$ sono partito [pp senza ne].

[I] of.them have left without

c. *Di cosa sei partito [pp senza eөsa]?

of what [you] have left without

d. [Senza cosa] sei partito senza cosa? without what [you] have left

Since temporal complements are always adjuncts, we expect them to always disallow extraction. This is indeed the case. In (20), the DP complement of the temporal preposition dopo 'after' cannot be extracted out of the PP adjunct, either as a clitic pronoun (20b) or a wh-phrase (20c); as above, pied piping is obligatory (20d). The same pattern is found with the temporal PP in (21), whose head selects a PP headed by $d i$ 'of'. Rizzi (1988/2001:538) observes that the complement of prima cannot be extracted via the clitic pronoun ne (21b). Note that wh-extraction is also ungrammatical (21c), and pied-piping is required as above, (21d):

(20) a. Ho parlato [pP dopo [DP Gianni]].

[I] have spoken after Gianni

b. ${ }^{*}$ '’ho parlato [pp dopo 10$]$.

[I] him have spoken after

c. *Chi hai parlato [pp dopo ehi]?

whom [you] have spoken after

d. [рP Dopo chi] hai parlato dope ehi? after whom [you] have spoken

(21) a. Gianni verrà [pp prima [pp di Mario]].

Gianni will.come before of Mario

'Gianni will come before Mario' 
b. *Gianni ne verrà [pp prima ne].

Gianni of.him will.come before

c. *Di chi verrà [pp prima di ehi]?

of whom [he] will.come before

d. [PP Prima di chi] verrà prima di-chi?

before of whom [he] will.come

The quantified nominal expression in (11) and the prepositional phrases in (15), (20), (21), and (19) are adjunct islands out of which extraction is impossible (cf. Huang's 1982 CED condition and recent reformulations in the minimalist framework by Chomsky 1995). These data show that clitic pronouns are moved from their first merge position, as in Kayne's (1975) original analysis of cliticization.

Finally note that clitic pronouns cannot be moved out of argumental PPs (from Belletti \& Rizzi 1981):

(22) a. Mi sono concentrato [PP su [QP alcuni [DP problemi]]].

[I] myself have concentrated on some problems

b. *Me ne sono concentrato [PP su [QP alcuni ne]].

[I] myself of.them have concentrated on some

Belletti \& Rizzi (1981) attribute the ungrammaticality of (22) to a violation of subjacency, confirming the movement nature of clitic placement. We come back to these examples in sections 4 and 6 below.

\section{The inventory of clitic pronouns}

Clitic pronouns may realise different types of complements. Romance languages differ with regard to which clitic pronouns are present in their lexicon (see Loporcaro 2010:note 25 and Paoli 2009, 2014). Consider Italian, which among the Romance languages contains the richest inventory of clitic pronouns. Clitic pronouns may realise a number of complements, as shown in (23) and (24). In (23), primary complements of the verb are exemplified (accusative, partitive, dative, matter, directional, locative, manner), in (24) secondary complements (benefactive, locative, comitative, instrumental): ${ }^{3}$

(23) a. Ho mangiato un panino.

[I] have eaten a sandwich

b. Ho mangiato un panino.

[I] have eaten a sandwich

c. Ho parlato a Gianni.

[I] have spoken to Gianni

d. Ho parlato di questo.

[I] have spoken about this

e. Sono uscita da quella situazione.

[I] have come.out from that situation

f. Vado a Roma.

[I] go to Rome a' L'ho mangiato.

[I] it have eaten

b' Ne ho mangiato uno.

[I] of.them have eaten one

c' Gli ho parlato.

[I] to.him have spoken

d' Ne ho parlato.

[I] of.it have spoken

e' Ne sono uscita.

[I] from.it have come.out

f' Ci vado.

[I] there go

\footnotetext{
${ }^{3}$ Italian displays some syncretisms in the clitic system. Ne stands for genitive/partitive and locative complements; $c i$ stands for directional, locative, comitative, and instrumental. Similar syncretisms are well-known in case systems (cf. Caha 2009). This is expected given that clitic pronouns realize morphological case (see section 6).
} 
g. Passo sempre per quella strada.

[I] pass always through that street

h. Abito a Roma.

[I] live in Rome

i. Mi comporto sempre in malo modo.

[I] myself behave always in bad way

(24) a. A Gianni è nato un bambino.

to Gianni is born a child

b. Ho già mangiato in quel ristorante.

[I] have already eaten in that restaurant

c. Ho parlato con Gianni.

[I] have spoken with Gianni

d. Lavoro con Gianni.

[I] work with Gianni

e. Ho aperto la scatola con le forbici.

[I] have opened the box with the scissors g' Ci passo sempre.

[I] through.it pass always

h' Ci abito.

[I] there live

i' Mi ci comporto sempre.

[I] myself so behave always

a' Gli è nato un bambino.

to.him is born a child

b' Ci ho già mangiato.

[I] there have already eaten

c' Ci ho parlato.

[I] with.him have spoken

d' Ci lavoro.

[I] with.him work

e' C'ho aperto la scatola.

[I] with.them have opened the box

It has been sporadically observed that clitic pronouns cannot realise other types of complements, such as temporal (25a,a') (from Cinque 1990:119) and locative adjuncts (25b,b') (Rizzi 1988/2001:541; 1990:127,n.9). If causal (25c,c') and manner adjuncts (25d,d') are added to the discussion, we arrive at the generalisation that complements external to the verbal phrase cannot be realised by clitic pronouns (Cardinaletti 2015):

(25) a. Rimarrò tre settimane.

[I] will-stay three weeks

b. Gianni è felice a casa dei genitori. Gianni is happy at home of-the parents

c. Piange per questo motivo.

[he] cries for this reason

d. Ha risolto il problema in questo modo. [he] has solved the problem in this way a'. $\quad$ *Spero di rimanerle in allegria.

[I] hope to stay-them in joy

b'. *Gianni ci è felice.

Gianni there is happy

c'. *Anche sua sorella ci/ne piange.

also his sister for.it cries

d'. $\quad * \mathbf{C i}$ ha risolto il problema.

[he] in.it has solved the problem

It is not clear why things should be this way. Note that (local) wh-movement of the same adjuncts is not restricted in the same way. Sentences (26) are not ungrammatical: ${ }^{4}$

(26) a. Quante settimane sei rimasto a Londra? how many weeks [you] are stayed in London

b. In quale città è felice, Gianni? in which city is happy, Gianni

c. Per quale motivo piange? for which reason [he] cries

d. In quale modo ha risolto il problema? in which way [he] has solved the problem

\footnotetext{
${ }^{4}$ For the restrictions on long adjunct movement, see Rizzi (1990:91).
} 
Since no locality constraint is violated in (26) and wh-movement is possible, the ungrammaticality of cliticization must be due to other reasons. The question is then: what excludes the cliticization of adjuncts? In the next section, we show that the restriction in (23)-(24) vs. (25) is indeed paralleled by the extraction possibilities of clitic pronouns that we have discussed in section 2 .

\section{A single generalization?}

We present the data again showing the existing parallelism between extraction and cliticization. Consider different types of locative complements. When the locative is an argument, as in the case of the verb abitare 'live', extraction of locative pronouns and wh-phrases are possible (27a,b) and cliticization via the locative pronoun $c i$ 'there' $(27 \mathrm{c})$ is also possible (see (23h')). The same is true of the locative complement of mangiare 'eat' in (28) (see (14b), (16b), (17b) above). In the case of the predicate essere felice, neither extraction (29a,b) nor cliticization of the locative adjunct is possible (29c) (see (15b), (16c), (17c) above):

(27) a. Gianni le ha abitato [accanto le] per molti anni. Gianni to.her has lived near for many years

b. A chi ha abitato [accanto chi]? to whom [he] has lived near?

c. Abito a Roma. Ci abito ei da tanti anni. [I] live in Rome. [I] there live for many years

(28) a. ?Gianni le ha mangiato [accanto te]. Gianni to-her has eaten near

b. ?A chi ha mangiato [accanto a chi]? to whom [he] has eaten near?

c. Gianni mangia sempre [in quel ristorante]. $\mathbf{C i}$ ha mangiato anche ieri ei. Gianni eats always in that restaurant. [he] there has eaten also yesterday

(29) a. *Gianni le è felice [accanto le]. Gianni to-her is happy near

b. *A chi è felice [accanto chi]? to whom [he] is happy near?

c. *(A casa dei genitori) Gianni ci è felice ei. (at home of-the parents) Gianni there is happy

Note that the locative complement of essere felice is a so-called frame locative, whose unmarked position is sentence-initial (30c), while the locatives occurring in (27) and (28) follow the verb in the unmarked word order, $(30 \mathrm{a}, \mathrm{b})$ :

(30) a. ??[A Roma] abito. in Rome [I] live

b. ??[In quel ristorante] Gianni mangia sempre. in that restaurant Gianni eats always

c. [A casa dei genitori] Gianni è felice. at home of-the parents Gianni is happy 
Now consider different types of manner complements. The argument in (31) allows extraction $(31 \mathrm{a}, \mathrm{b})$ (cf. (18b,c)) and can be cliticized (31c) (cf. (23i')), while the adjunct in (32) can neither (cf. (19b,c)):

(31) a. Ne sono rimasto [pp senza ne].

[I] of.them have remained without

b. Di cosa sei rimasto [Pp senza eosa]?

of what [you] have remained without

c. [Senza sigarette] non ci sono mai rimasto.

without cigarettes $[\mathrm{I}]$ not so have ever remained

(32) a. *Ne sono partito [pP senza ne].

[I] of.them have left without

b. *Di cosa sei partito [PP senza cosa]?

of what [you] have left without

c. *[Senza sigarette] non ci sono mai partito.

without cigarettes [I] not so have ever left

Finally, consider temporal adjuncts. It is not possible to extract the partitive pronoun ne (33a) (see (11b) above), nor to cliticize the temporal adjunct with the accusative pronoun le (33b) (see (25a') above). The same is true of the temporal PP in (34), out of which it is not possible to extract a clitic pronoun or a whphrase (see $(20 \mathrm{~b}, \mathrm{c})$ above) and which cannot be cliticized:

(33) a. Gianni è rimasto tre settimane a New York. *Ne è rimasto [tre ne] a Milano.

Gianni has remained three weeks in New York. [he] of.them has remained three in Milan

b. Rimarrò tre settimane. *Spero di rimanerle in allegria.

[I] will-stay three weeks. [I] hope to stay-them in joy

(34) a. Ho parlato dopo Gianni. *L'ho parlato [pp dopo 1 ].

[I] have spoken after Gianni. [I] him have spoken after

b. *Chi hai parlato [PP dopo ehi]?

whom [you] have spoken after

We think that the parallelism between extraction and cliticization seen in (27)-(29), (31)-(32), and (33)(34) is not a coincidence, and the data can be expressed as a single generalization: the complements that allow extraction can be cliticized.

We claim that this generalization can be explained by a single hypothesis, namely the so-called big DP hypothesis meant to capture the phenomenon of clitic doubling. Consider the dative clitic pronoun doubling the indirect object in Spanish (35a) (Demonte 1995) and the nominative clitic pronoun doubling the subject in the Trentino dialect (35b) (Brandi \& Cordin 1981, 1989; Belletti 1999) and in Portuguese (35c) (Martins 2009):

(35) a. Le entregué las llaves al conserje.

[I] to.him gave the keys to-the janitor

'I gave the keys to the janitor'

b. Nane el vien doman.

'Nane he is coming tomorrow' 
c. A gente chama-se rãs a isto.

'We call these ones frogs'

In (35), an argument is realized twice: by a clitic pronoun and an associate DP/PP. In order to avoid a violation of the Theta criterion, the clitic pronoun and the associate DP/PP are taken to be merged as a single constituent, a so-called "big" DP (cf. Torrego, 1986, 1995; Uriagereka, 1995, 2005; Belletti, 1999, 2005; Cecchetto, 2000; Martins, 2009, among others).

In the spirit of Sportiche (1996/98), the big DP hypothesis allows us to offer one and the same analysis to clitic doubling configurations and simple cliticization cases. Sportiche assumed that clitic pronouns are merged as functional heads in the clausal spine and the difference between the two cases consists in the insertion of a DP or a small pro, respectively, in the argument position. Keeping the advantages of his proposal, I suggest that clitic pronouns are always merged as constituents of big DPs and that in the case of simple cliticization, the structure is the same as in the case of clitic doubling but for the null realization of the associate DP (cf. Belletti, 1999).

This hypothesis allow us to understand the parallelism between the extraction possibilities and the cliticization possibilities. If cliticization is extraction of the clitic pronoun out of a big DP, there won't be any cliticization out of adjuncts. As we have seen in section 2 and in the data repeated in this section, adjuncts do not allow extraction of either clitic pronouns or wh-phrases. Cliticization is only possible out of VP-internal complements, out of which extraction is shown to be independently possible (cf. (27a,b), (28a,b), (31a,b)).

This generalization also applies to clauses, which allow extraction (36c) and can be cliticized (36d). The ungrammaticality of clitic extraction as in (36b) is due to independent reasons, i.e., the local character of clitic movement, which is an instance of A-movement followed by head movement (see section 1 above):

(36) a. Ha detto [che ha visto Maria].

[he] has said that [he] has seen Maria

'He said that he saw Maria'

b. *L'ha detto [che ha visto ta].

[he] her has said that [he] has seen

c. Chi ha detto [che ha visto ehi]?

who [he] has said that [he] has seen

d. [Che ha visto Maria], lo ha detto to. that [he] has seen Maria [he] it has said

Consider now apparent counterexamples to our generalization, namely PPs out of which clitic extraction is not possible, as in (37b) (see (22) above), but which can nonetheless be cliticized, (37c). The same pattern is found with all PPs listed in (23c-i) and (24). PPs also block movement of their complements $(38 \mathrm{~b}, \mathrm{c})$ :

(37) a. Mi sono concentrato [PP su [QP alcuni [DP problemi]]].

[I] myself have concentrated on some problems

b. *(Di problemi) me ne sono concentrato [PP su [QP alcuni ne]].

of problems, [I] myself of.them have concentrated on some

c. (Su alcuni problemi) mi ci sono concentrato ei.

on some problems, [I] myself on.them have concentrated

(38) a. Mi sono concentrato [PP Su [DP questi problemi]].

[I] myself have concentrated on these problems 
b. *Mi li sono concentrato [pp su li].

[I] myself them have concentrated on

c. *Cosa ti sei concentrato [Pp su eosa]?

what [you] have concentrated on

These cases are not counterexamples to our proposal given that the PPs are arguments and in principle not islands to extraction. Cliticization as in (37c) is therefore expected. The ungrammaticality of (37b) and $(38 \mathrm{~b}, \mathrm{c})$ is due to independent reasons. We come back to these cases in section 6 , where we develop a reanalysis of the big DP hypothesis. For the time being, in (39) we summarize the correlation between extraction and cliticization. Note that there is no situation in which extraction is possible and cliticization is ungrammatical (39f):

\begin{tabular}{|c|l|l|l|l|}
\hline$(39)$ & & Clitic extraction & Wh-extraction & Cliticization \\
\hline a. & Argument DP & OK & OK & OK \\
\hline b. & Argument PP (lexical preposition) & OK & OK & OK \\
\hline c. & Argument CP & $*$ & OK & OK \\
\hline d. & Argument PP (functional preposition) & $*$ & $*$ & OK \\
\hline e. & Adjunct & $*$ & $*$ & $*$ \\
\hline f. & $*$ & OK & OK & $*$ \\
\hline
\end{tabular}

\section{The internal structure of big DPs}

In this section, the internal structure of big DPs is discussed in detail. Two hypotheses have been put forward in the literature: the associate DP occurs in the specifier of the big DP, as in (40a) (Torrego, 1995; Uriagereka, 1995, 2005), or as complement to D, as in (40b) (Belletti, 1999, 2005; Cecchetto, 2000; Papangeli, 2000):

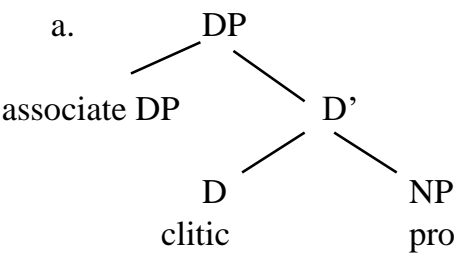

b.

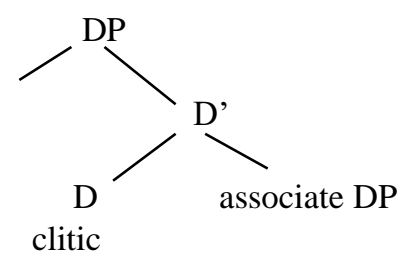

In both hypotheses, the clitic pronoun is analyzed as the D head of the big DP (and undergoes head movement to its spell-out position). As we have seen in section 1, however, there is evidence that clitic pronouns are maximal projections and not heads during the first step(s) of their syntactic derivation 
(Sportiche, 1989/98; Belletti, 1999; Cardinaletti \& Starke, 1999; Rizzi, 2000). This speaks against movement of the clitic pronoun out of structures like (40). ${ }^{5}$

Following Cardinaletti \& Starke (1999), I take clitic pronouns to realize reduced nominal expressions, lacking the highest functional layer of nominal expressions. In the current hypothesis that nominal phifeatures are encoded in a functional projection IP (41), structurally parallel to the clausal projection which encodes verbal inflection, the structure of clitic pronouns can be represented as in (42), where the DP projection is missing (and the NP is not overtly realized):

(41) Nominal expressions and strong pronouns

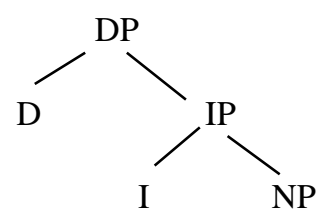

(42) Clitic pronouns<smiles>[PH][In]I</smiles>

Given this assumption, the structure of the big DP seen above in (40) should be reformulated. I suggest that clitic pronouns are merged as specifiers of big DPs, represented as XP in (43). As anticipated in section 4 above, the structure is the same when the clitic pronoun occurs by itself as in (43a) and when it reduplicates a nominal expression in clitic doubling constructions, as in $(43 \mathrm{~b}):^{6}$

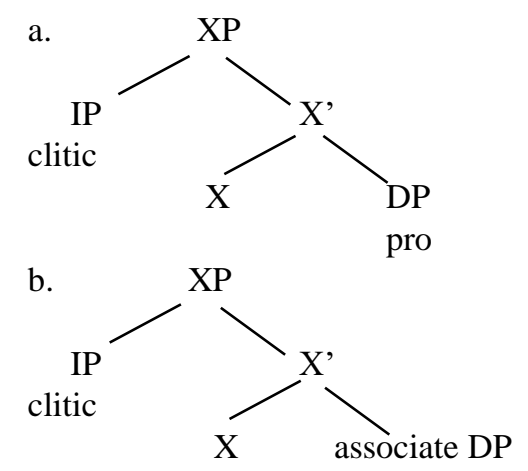

\footnotetext{
${ }^{5}$ In addition to the evidence provided by past-participle agreement, there is substantial independent evidence that clitic pronouns and definite articles are not realizations of one and the same lexical element, nor do they realise the same syntactic category D. See the arguments presented in Cardinaletti (2015) and (2016).

${ }^{6}$ We will not attempt at explaining why clitic doubling is not possible in all languages which display clitic pronouns. In the view that [ \pm pronunciation of functional elements] is a possible source of cross-linguistic variation (e.g. Kayne 2005), the availability of clitic doubling may be due to the positive value of this parameter.
} 
As for the nature of the $\mathrm{X}$ head in (43), I suggest that it encodes case features. The big DP should therefore be represented as $\mathrm{K}($ ase $) \mathrm{P}$. The proposal that $\mathrm{KP}$ is the highest projection of nominal expressions is not new in the literature: cf. Giusti (1993), (1997); Bittner \& Hale (1996); Cardinaletti \& Starke (1999); Caha (2009), among others:

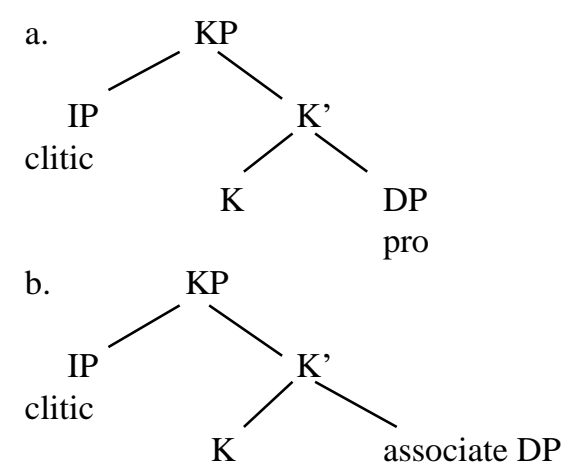

Note that in the clitic doubling configurations in $(35 \mathrm{a}, \mathrm{b})$, clitic pronouns share the case and the phifeatures of the associate DP. This observation can be captured by adopting general syntactic principles. In (44), the clitic pronoun and the K head are in a spec-head configuration and share the case feature; the K head in turn shares the phi-features of its DP complement in that it realizes its highest functional projection. For the proposal that all the fucntional heads in the extended projection of the noun share the features of the noun, cf. Giusti (2015).

\section{Going back to the generalization on extraction and cliticization}

In the previous section, we have suggested that clitic pronouns are constituents of big DPs merged as their specifiers. This proposal implies that the cliticization process is extraction out of big DPs. As anticipated in section 4 , this allows us to understand why adjuncts, out of which extraction is not possible, cannot be cliticized either. If cliticization is indeed extraction out of a big DP, we expect it not to be possible out of adjuncts. We however expect that argumental expressions, out of which extraction is possible, can also be cliticized. This is indeed the case, as we have seen in section 4.

In section 4, one case was left unanalyzed: the case of argumental PPs, out of which extraction is not possible, but which can nonetheless be cliticized, cf. (37). We repeat the relevant case in (45) and (46), but the same configuration is found in all the examples in (23c-i) and (24), in which clitic pronouns stand for nominal expressions introduced by a preposition, here marked as PPs for the sake of convenience:

(45) a. Mi sono concentrato [PP Su [QP alcuni [DP problemi]]].

[I] myself have concentrated on some problems

b. *(Di problemi) me ne sono concentrato [PP su [QP alcuni ne]].

(of problems) [I] myself of.them have concentrated on some

c. (Su alcuni problemi) mi ci sono concentrato ei.

(on some problems) [I] myself on.them have concentrated

(46) a. Mi sono concentrato [PP su [DP questi problemi]].

[I] myself have concentrated on these problems 
b. *Mi li sono concentrato [PP su li].

[I] them have concentrated on

c. *Cosa ti sei concentrato [pP su eosa]?

what [you] have concentrated on

d. (Su questi problemi) mi ci sono concentrato ei.

(on these problems) [I] myself on.them have concentrated

To account for the cliticization case in (45c) and (46d), I assume the structure in (44a); KP is merged, out of which a clitic pronoun can be extracted. This also explains why clitic pronouns display case morphology. As said above, they stand in a spec-head configuration with the case head.

The question is now: why do the same arguments not allow extraction when the DP is present and a preposition is merged? This happens in $(45 \mathrm{~b}),(46 \mathrm{~b}, \mathrm{c})$, and all the cases in $(23 \mathrm{c}-\mathrm{i})$ and $(24){ }^{7}$

In Caha's (2009) approach to case, according to which different case layers are on top of DPs, prepositions realize case layers higher than the landing site of DP movement. In languages like Italian, DPs move no higher than nominative and accusative case, for subject and direct objects, respectively. Prepositions appear with all other complements. In the case of clitic pronouns, no preposition is realized because the clitic pronouns move through the different case layers in order to be extracted.

As currently assumed, extraction out of PPs violates locality. If the PP is crossed, a PIC violation is incurred (Phase Impenetrability Condition, Chomsky 2000). Another derivation is blocked as well. If the extracted element first moves to the PP, an anti-locality violation occurs. According to Abels (2003) and Grohmann (2003), anti-locality blocks movements that are too short in that they do not cross a full phrase.

Note that our account correctly predicts that the mirror situation is never found, namely a configuration which allows extraction but blocks cliticization (see (39f) above). If a configuration allows extraction, it will necessarily also allow cliticization, which by hypothesis is a subcase of extraction.

\section{Conclusions}

In this paper, we have discussed the following generalization: complements that allow extraction can be cliticized. We have suggested that clitic pronouns are merged as constituents of big DPs, out of which they are extracted. Cliticization is thus to be seen as an instance of extraction. This allows us to explain why clitic pronouns cannot stand for adjunct complements. We also claim that the highest functional projection of big DPs encodes case. Clitic pronouns agree in case and phi-features with the associate DP, be it null, as in simple cliticization, or overt, as in clitic doubling.

\section{References}

Abels, Klaus (2003) Successive cyclicity, anti-locality, and adposition stranding. PhD dissertation, University of Connecticut.

Belletti, Adriana (1999) Italian/Romance clitics: Structure and derivation. In Henk van Riemsdijk (ed.) Clitics in the Languages of Europe. Mouton, Berlin-New York, pp. 543-579.

Belletti, Adriana (2005) Extended doubling and the VP-periphery. Probus 17, pp. 1-35.

Belletti, Adriana \& Luigi Rizzi (1981) The syntax of ne: Some theoretical implications. The Linguistic Review 1, pp. 117-154.

Bittner, Maria \& Kenneth Hale (1996) The Structural Determination of Case and Agreement. Linguistic

\footnotetext{
7 In languages that allow preposition stranding, similar sentences are grammatical. We do not discuss these cases here.
} 
Inquiry 27, pp. 1-68.

Brandi, Luciana, Patrizia Cordin (1981) Dialetti and italiano: un confronto sul parametro del soggetto nullo. Rivista di grammatica generativa 6, pp. 33-87.

Brandi, Luciana \& Patrizia Cordin (1989) Two Italian dialects and the null subject parameter. In Osvaldo Jaeggli and Ken Safir (eds.) The Null Subject Parameter. Dordrecht: Kluwer, pp. 111-142.

Caha, Pavel (2009) The nanosyntax of case. PhD dissertation, University of Troms $\emptyset$.

Cardinaletti, Anna (1994) On the internal structure of pronominal DPs. The Linguistic Review 11, pp. 195219.

Cardinaletti, Anna (2015) Syntactic effects of cliticization. In Tibor Kiss and Artemis Alexiadou (eds.) Syntax - Theory and Analysis. An International Handbook. Berlin: De Gruyter Mouton, vol. 42/1, pp. 595-653.

Cardinaletti, Anna (2016) Sui limiti dei pronomi clitici: inventario ed estrazione. In Adam Ledgeway, Michela Cennamo and Guido Mensching (eds.) Actes du XXVIIe Congrès international de linguistique et de philologie romanes (Nancy, 15-20 juillet 2013). Section 4: Syntaxe. Nancy: ATILF, pp. 48-62.

Cardinaletti, Anna \& Giuliana Giusti (2006) The syntax of quantified phrases and quantitative clitics. In Martin Everaert and Henk van Riemsdijk (eds.) The Blackwell Companion to Syntax. Oxford: Blackwell Publishers Ltd, vol. V, pp. 23-93.

Cardinaletti, Anna \& Giusti, Giuliana (2017) Quantified Expressions and Quantitative Clitics. In Martin Everaert and Henk van Riemsdijk (eds.) The Wiley Blackwell Companion to Syntax. Second Edition. London: Wiley Blackwell, pp. 1-61.

Cardinaletti, Anna \& Michal Starke (1999) The typology of structural deficiency: A case study of the three classes of pronouns. In Henk van Riemsdijk (ed.) Clitics in the Languages of Europe, EALT/EUROTYP 20-5. Mouton: Berlin-New York, pp. 145-233.

Cecchetto, Carlo (2000) Doubling structures and reconstruction. Probus 12, pp. 93-126.

Chomsky, Noam (1995) The Minimalist Program. Cambridge, Mass.: MIT Press.

Chomsky, Noam (2000) Minimalist Inquiries: the Framework. In Roger Martin, David Michaels and Juan Uriagereka (eds.) Step by step. Cambridge, MA: MIT Press, pp. 89-156.

Cinque, Guglielmo (1990) Types of A'Dependencies. Cambridge, Mass.: MIT Press.

Corver, Norbert \& Denis Delfitto (1999) On the nature of pronoun movement. In Henk van Riemsdijk (ed.), Clitics in the Languages of Europe, EALT/EUROTYP 20-5. Mouton: Berlin-New York, pp. 799-861.

Demonte, Violeta (1995) Dative alternations in Spanish. Probus 7, pp. 5-30.

Giusti, Giuliana (1993) La sintassi dei determinanti. Padova: Unipress.

Giusti, Giuliana (1997) The categorical status of determiners. In Liliane Haegeman (ed.), The New Comparative Syntax. Longman: London, pp. 95-123.

Giusti, Giuliana (2015) Nominal Syntax at the interfaces. A comparative study of languages with articles. Newcastle upon Tyne: Cambridge Scholars Publishing.

Grohmann, Kleanthes (2003) Prolific Domains: On the Anti-locality of Movement Dependencies. Amsterdam: John Benjamins Publishing.

Huang, J. (1982) Logical relations in Chinese and the theory of grammar. Ph.D. Dissertation, MIT.

Jaeggli, Osvaldo (1982) Topics in Romance Syntax. Dordrecht: Foris.

Kayne, Richard (1975) French Syntax. Cambridge, Mass.: MIT Press.

Kayne, Richard (1989) Facets of Romance past participle agreement. In Paola Benincà (ed.), Dialect Variation and the Theory of Grammar. Dordrecht: Foris, pp. 85-103.

Kayne, Richard S. (2005) Some notes on comparative syntax, with special reference to English and French. In Guglielmo Cinque and Richard Kayne (eds.), Handbook of Comparative Syntax. Oxford: Oxford University Press, pp. 3-69.

Papangeli, D. (2000) Clitic doubling in Modern Greek: a Head-Complement relation. UCL working papers in 
Linguistics 12, 473-499.

Rizzi, Luigi (1988/2001) Il sintagma preposizionale. In Lorenzo Renzi, Giampaolo Salvi and Anna Cardinaletti (eds.) Grande grammatica italiana di consultazione. Bologna: il Mulino, vol.1, pp. 521-545 (1st ed. 1988).

Rizzi, Luigi (1990) Relativized Minimality. Cambridge, Mass.: MIT Press.

Rizzi, Luigi (2000) Some notes on Romance cliticization. In Comparative Syntax and Language Acquisition. London: Routledge, pp. 96-121.

Siloni, Tali (1997) Noun Phrases and Nominalizations. The Syntax of DPs. Dordrecht: Kluwer.

Sportiche, Dominique (1996/98) Clitic constructions. In Johan Rooryck and Laurie Zaring (eds.), Phrase Structure and the Lexicon. Dordrecht: Kluwer, pp. 213-276.

Sportiche, Dominique (1989/98) Movement, agreement and case, ms., UCLA, published in 1998 in Partition and Atoms of Clause Structure. London: Routledge, pp. 88-243.

Torrego, Esther (1995) On the nature of clitic doubling. In Hector Campos and Paula Kempchinsky (eds.) Evolution and Revolution in linguistic Theory: Washington, DC: Georgetown University Press, pp. 399418.

Uriagereka, Juan (1995) Aspects of the syntax of clitic placement in Western Romance. Linguistic Inquiry 26, pp. 79-124.

Uriagereka, Juan (2005) On the syntax of doubling. In Lorie Heggie and Francisco Ordóñez (eds.) Clitic and Affix combinations. Amsterdam/Philadelphia: John Benjamins, pp. 343-374. 